\title{
KEEPING THE SEA OUT: EARLY MEDIEVAL STRUCTURES AT CA' FOSCARI UNIVERSITY, VENICE, ITALY
}

\author{
John Meadows ${ }^{1} \cdot$ Nicoletta Martinelli $^{2}$ - Olivia Pignatelli ${ }^{2} \cdot$ Rossella Cester $^{3} \bullet$ \\ Luigi Fozzati ${ }^{4}$ Bernd Kromer $^{5}$
}

\begin{abstract}
In 2004, the courtyard of Ca' Foscari University, Venice, was excavated in advance of building work, revealing an unbroken sequence of archaeological deposits. The earliest layers consisted of redeposited natural sediment, packed into wattle structures, a system of land reclamation first described by Cassiodorus in AD 537-8, and now known from several other sites in the city. The ground level was built up and extended several times with successive wattle structures, before the eventual construction of a stone waterfront. We have used Bayesian modeling of dendrochronological, radiocarbon, and stratigraphic dating evidence to obtain a precise chronology for the earliest phases of occupation, and to compare it to the chronology of land reclamation at similar sites elsewhere in Venice.
\end{abstract}

\section{INTRODUCTION}

Islands in the Venetian lagoon were settled intensively in the 5th and 6th centuries $\mathrm{AD}$, following the collapse of Roman authority on the mainland in the aftermath of barbarian invasions. Until the 9th century, settlements elsewhere in the lagoon (e.g. Torcello, Malamocco, San Francesco del Deserto) appear to have been more important than the site of Venice itself. The history of these early settlements is poorly documented, but a useful description is given in a letter written by Cassiodorus, a minister of the Ostrogoth king Witiges, to the Tribuni Maritimorum, officials responsible for their administration, in AD 537-8. Cassiodorus described the method used to reclaim land as the settlements grew: Viminibus enim flexibilibus illigatis terrena illic soliditas aggregatur et marino fluctui tam fragilis munitio non dubitatur opponi ("there the earth is consolidated with interwoven wattles, and such fragile structures are built confidently against the waves of the sea"). These flexible wooden structures (volparoni) were filled with sediment from adjacent sandbanks, simultaneously extending the land area, raising the ground level, and deepening surrounding channels.

This initial phase of consolidation was first recorded archaeologically at sites in the eastern lagoon (Canal 1998). In Venice itself, boreholes at San Lorenzo, near San Marco, produced several radiocarbon results on structural timbers indicating occupation in the 6th-7th century cal AD (Ammerman et al. 1992), but only in the last decade has it become feasible to excavate volparoni structures, during the mandatory installation of deep cisterns when major buildings (palazzi) are restored. Volparoni structures are often encountered at about $1.5 \mathrm{~m}$ below mean sea level, but their complete horizontal and vertical exposure has not been possible, because of the restrictive working conditions in rescue archaeology. One of the most extensive recent investigations is the excavation in the courtyard of Palazzo Ca' Foscari, the seat of the University of Venice, in 2004 (Figure 1).

\footnotetext{
${ }^{1}$ Zentrum für Baltische und Skandinavische Archäologie, Schloss Gottorf, 24837 Schleswig, Germany; Leibniz-Labor für Altersbestimmung und Isotopenforschung, Christian-Albrechts-Universität zu Kiel, Max-Eyth-Str. 11-13, 24118 Kiel, Germany. Corresponding author. Email: jmeadows@leibniz.uni-kiel.de.

${ }^{2}$ Dendrodata s.a.s., via Cesiolo 18, Verona 37126, Italy.

${ }^{3}$ Studio Associato Bettinardi Cester Archeologi, S. Croce, 2259, Venezia 30135, Italy.

${ }^{4}$ Soprintendenza per i Beni Archeologici del Friuli Venezia Giulia, viale Miramare 9, 34135 Trieste, Italy.

${ }^{5}$ Heidelberger Akademie der Wissenschaften, c/o Institut für Umweltphysik, Universität Heidelberg, Im Neuenheimer Feld 229, 69120 Heidelberg, Germany.
}

C 2012 by the Arizona Board of Regents on behalf of the University of Arizona Proceedings of the 6th International Radiocarbon and Archaeology Symposium, edited by E Boaretto and N R Rebollo Franco RADIOCARBON, Vol 54, Nr 3-4, 2012, p 567-579 


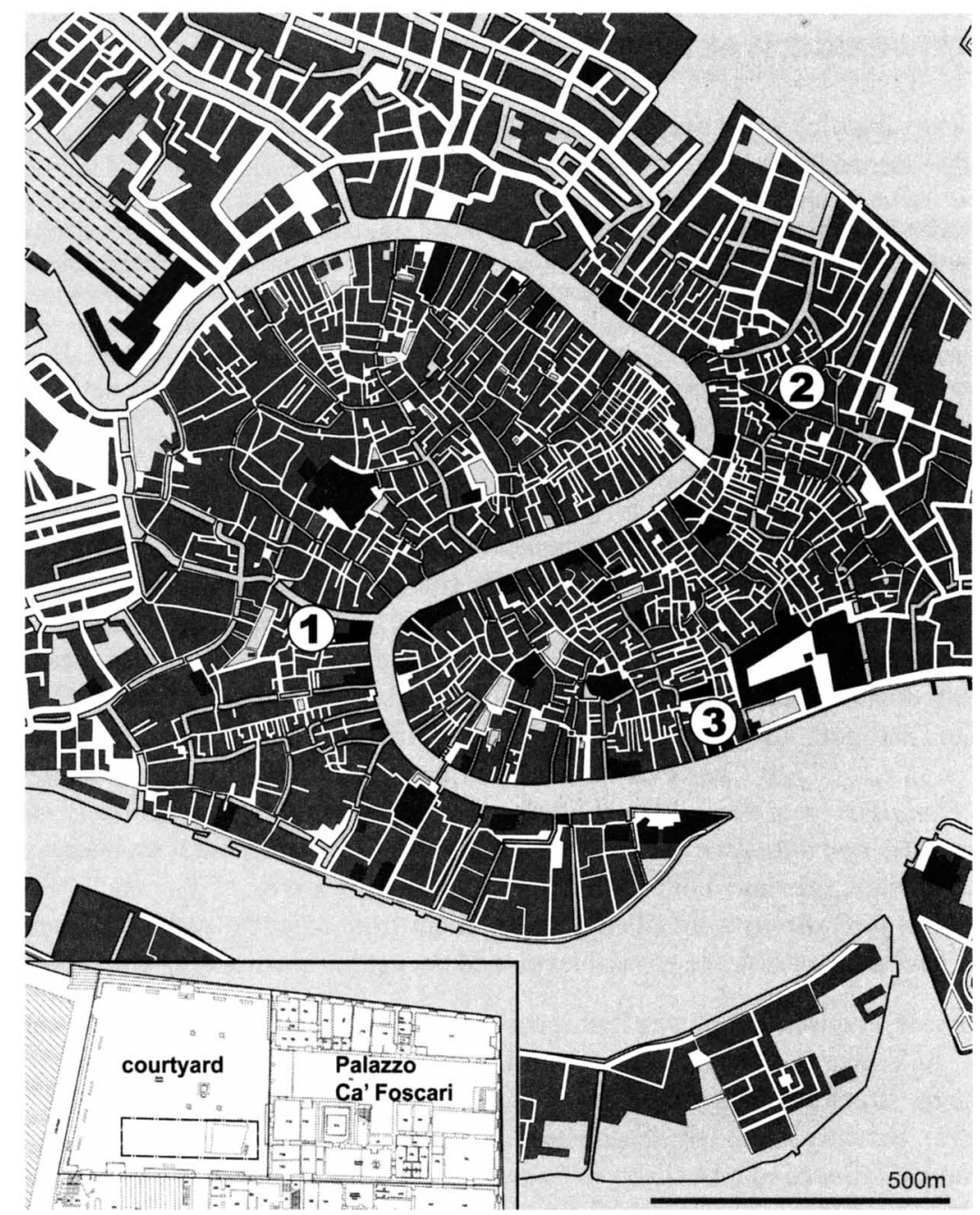

Figure 1 Map of central Venice, Italy, showing locations of sites where volparoni structures have been dated: 1) Ca' Foscari; 2) Teatro Malibran; 3) ex-Cinema San Marco. Inset: the 22-m-long excavated area (dashed line) in the courtyard of Palazzo Ca' Foscari. Based on a figure in Fozzati and Cester (2005).

\section{SITE DESCRIPTION}

Archaeological investigation at $\mathrm{Ca}$ ' Foscari began in 2002, when 6 boreholes were drilled to a depth of $6 \mathrm{~m}$ below the courtyard surface, to determine the extent of anthropogenic deposits. Wooden structures were found at about $3 \mathrm{~m}$ depth, or $\sim 1.5 \mathrm{~m}$ below present mean sea level, and a single ${ }^{14} \mathrm{C}$ sample confirmed the late antique/early Medieval date of this timber (Rome-1598, $1460 \pm 50 \mathrm{BP}$, cal AD 470-660).

An area $22 \times 5.5 \mathrm{~m}$ was excavated in the courtyard in 2004 , to the permitted depth of $1.8 \mathrm{~m}$ below mean sea level, without reaching archaeologically sterile deposits. A stratigraphic sequence of 14 phases was distinguished, beginning with volparoni structures extending from the east to the center, with later deposits, including an infilled canal, at the western end of the trench (Fozzati and Cester 2005). 
The earliest structures consisted of lines of wooden posts, with interwoven branches of various species (see below). Layers of sediment were dumped behind these volparoni, to raise and expand the area around what must have been a natural topographic high point. The dumped layers contain the foraminifer Trochammina inflata, characteristic of intertidal flats or sandbanks in the lagoon, suggesting that the sediment was obtained from partly submerged areas. Strand-lines of plant debris on the raised ground surface are related to the construction of a second phase of volparoni. This phase is more complex, including 2 episodes of consolidation and 2 occupation levels. The earlier series of structures follows the same north-south alignment of the first phase, while the second series forms an arc from north-east to north-west. Again, the occupation levels are rich in plant debris, including reed matting in the upper level (Figure 2). The occupation level for the third volparoni phase, whose structures include a probably temporary plank walkway, is about $1 \mathrm{~m}$ higher than the earliest recorded occupation level. These phases did not yield closely datable finds.

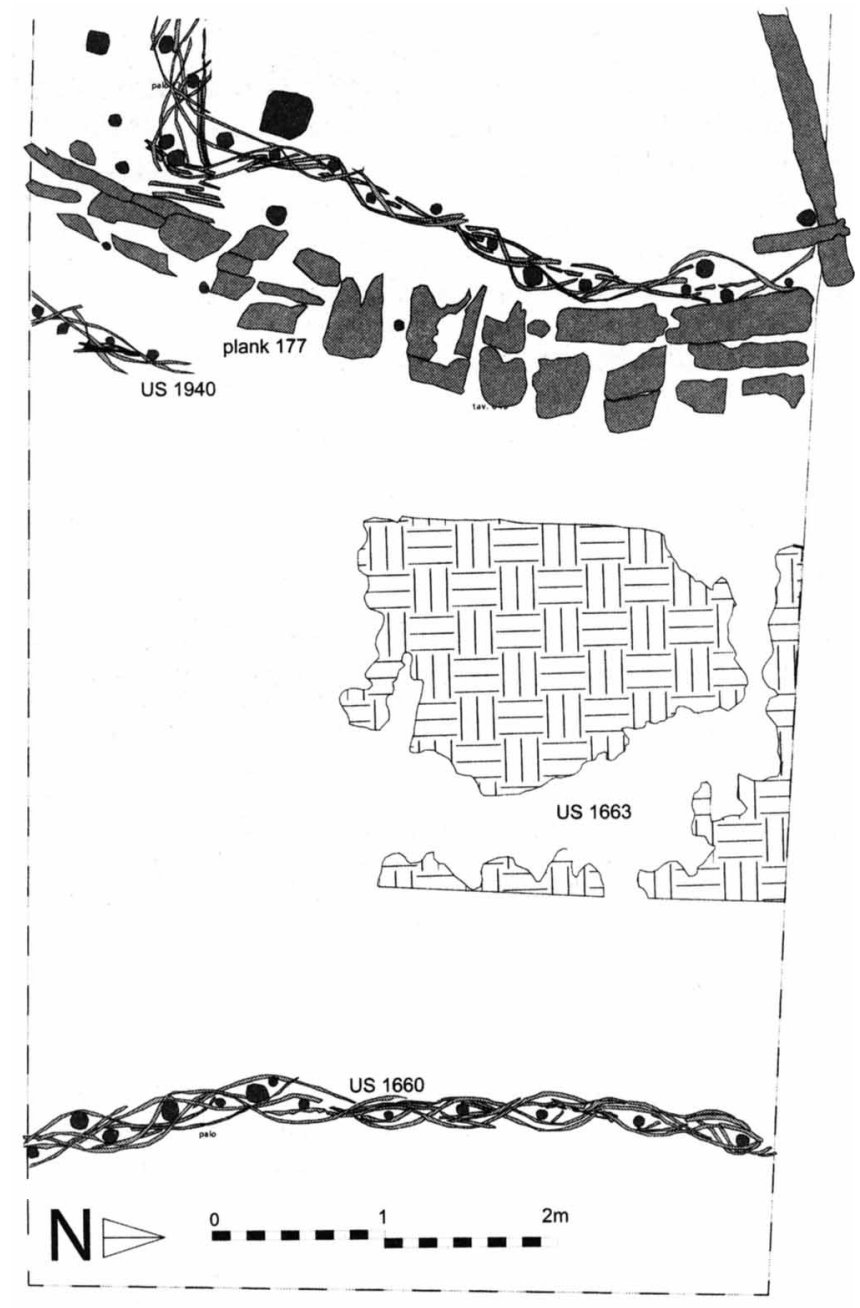

Figure 2 Plan of the eastern end of the $\mathrm{Ca}$ ' Foscari courtyard trench, showing 3 of the volparoni structures, the timber walkway and reed matting (US 1663). Based on a figure in Fozzati and Cester (2005). 
A fourth phase comprises a series of dumped layers and occupation levels, with artifacts ranging in date from Roman building materials to coarse pottery and amphorae of the 7th-8th centuries AD, and, from one of the occupation levels, $\sim 0.2 \mathrm{~m}$ below modern mean sea level, a Byzantine coin struck in AD 518-522. In the next phase, these occupation levels were partly covered by natural sandy layers. The sixth phase is marked by the construction of a timber waterfront, downslope at $1.3 \mathrm{~m}$ below modern sea level. After several further layers accumulated both by natural processes and intentional deposition, a new waterfront was built, in stone. Only its base remains, but associated backfills and occupation levels suggest that it reached to at least $0.5 \mathrm{~m}$ below modern sea level. Later phases consist of a series of dumps of building rubble that filled in the associated canal, creating a level surface on which a timber building was raised in the 13th century. Since the 15 th century, when Palazzo $\mathrm{Ca}$ ' Foscari was built, the area has been an open courtyard.

\section{MATERIALS AND METHODS}

Scientific dating efforts were focussed on the initial phases of occupation, associated with volparoni and contemporary wooden structures. Six timbers were suitable for dendrochronological analysis, 10 were selected for ${ }^{14} \mathrm{C}$ dating, and a further 60 wood samples were selected for species identification. In all, 28 timbers were identified as deciduous oak (Quercus sp. sect. Robur), 19 as elm (Ulmus sp.), 14 as alder (Alnus sp.), 4 as hazel (Corylus avellana L.), 3 as hornbeam (Carpinus betulus L.), 3 as willow (Salix sp.), and 2 as Pomoideae. Single specimens of maple (Acer sp.), ash (Fraxinus sp.), and hophornbeam/hornbeam (Ostrya/Carpinus) were identified.

Six samples, from 1 post and 5 planks, were submitted to dendrochronological analysis. Three samples (the post, a vertical and a horizontal plank) were oak timbers, from the structures US 50, US 184, and US 1879 (Table 1). Elm (Ulmus sp.) timbers from structures US 177, US 186, and US 193 were also analyzed (Table 1). Unfortunately, almost all timbers in volparoni structures were rejected, either because the species concerned is unsuitable for dendrochronological analysis, or because the number of growth rings was inadequate.

Standard dendrochronological methods were followed (Fritts 1976; Baillie 1982). Tree rings were measured from pith to bark-edge using the LINTAB device (F Rinn, Heidelberg, Germany), to a precision of $0.01 \mathrm{~mm}$. Data were recorded and processed using the software TSAP ${ }^{\circledR}$ (Rinntech 2003) and CATRAS ${ }^{\circledR}$ (Aniol 1983).

Table 1 Dendrochronological samples of Ca' Foscari. Cross-matching positions for the final ring in each sample are given relative to the 250 -yr floating regional oak chronology for eastern Veneto (Martinelli and Kromer 2002).

\begin{tabular}{lllllll}
\hline Sample & Species & Rings & Center & $\begin{array}{l}\text { Sap- } \\
\text { wood }\end{array}$ & $\begin{array}{l}\text { Bark- } \\
\text { edge }\end{array}$ & $\begin{array}{l}\text { Cross- } \\
\text { match }\end{array}$ \\
\hline plank US 1879 & oak (Quercus sp. sect. Robur) & 70 & - & - & - & year 199 \\
plank US 184 & oak (Quercus sp. sect. Robur) & 60 & - & - & - & - \\
plank US 177 & elm (Ulmus sp.) & 95 & - & - & uncertain & year 226 \\
post US 50 & oak (Quercus sp. sect. Robur) & 90 & - & - & - & - \\
plank US 186 & elm (Ulmus sp.) & 81 & - & - & - & - \\
plank US 193 & elm (Ulmus sp.) & 41 & - & - & - & - \\
\hline
\end{tabular}

A single ${ }^{14} \mathrm{C}$ sample (4-US8) of unidentified worked wood from the 2002 boreholes was dated to confirm that the structures located at 1.5-1.6 m below mean sea level were of early Medieval date. Following the 2004 excavation, $10{ }^{14} \mathrm{C}$ samples were selected from as many structures (wattles from the volparoni structures US 1660, US 1757A, US 1814, US 1871, US 1882, US 1940, US 2000, and 
US 2121, and posts P226, P1292D; the last is from a later Medieval structure and is not discussed here). The outermost annual rings were sampled from each timber, which in every case was complete to the bark-edge. The number of annual rings in each ${ }^{14} \mathrm{C}$ sample was recorded (Table 2).

The 2002 sample was dated at the ${ }^{14} \mathrm{C}$ laboratory of the Istituto di Geologia Ambientale e Geoingegneria, Università "La Sapienza" di Roma. After manual inspection and cleaning, and acid-baseacid $(\mathrm{HCl}-\mathrm{NaOH}-\mathrm{HCl})$ pretreatment, the sample was converted to benzene and measured by liquid scintillation counting, according to methods described by Calderoni and Petrone (1992). The 2004 samples were dated by gas proportional counting at the University of Heidelberg Radiocarbon Laboratory. The wood samples $(n=11)$ were milled and pretreated using an acid-base-acid (ABA) sequence with $\mathrm{NaOH}$ overnight, $\mathrm{HCl}, \mathrm{NaOH}$, and $\mathrm{HCl}$ for $1 \mathrm{hr}$ each, all at $80{ }^{\circ} \mathrm{C}$. The wood was combusted in a de Vries-type combustion system, and the $\mathrm{CO}_{2}$ was purified. The samples were measured for 9-12 days in low-level gas counters (Kromer and Münnich 1992). The results reported in Table 2 are conventional ${ }^{14} \mathrm{C}$ ages (Stuiver and Polach 1977).

Table $2{ }^{14} \mathrm{C}$ results for Ca' Foscari. The calibrated ranges were obtained by the maximum intercept method (Stuiver and Reimer 1986), using the IntCal09 calibration curve (Reimer et al. 2009) and the program OxCal v 4.1 (Bronk Ramsey 2009).

\begin{tabular}{|c|c|c|c|c|c|}
\hline Sample & $\begin{array}{l}\text { Wood identification and } \\
\text { intrinsic age }\end{array}$ & Lab code & $\begin{array}{l}\delta^{13} \mathrm{C} \\
(\%) \\
\end{array}$ & $\begin{array}{l}{ }^{14} \mathrm{C} \text { age } \\
\text { (BP) }\end{array}$ & $\begin{array}{l}\text { Calibrated date } \\
(95 \% \text { confidence })\end{array}$ \\
\hline core 4-US 8 & - & Rome-1598 & - & $1460 \pm 50$ & cal AD 470-660 \\
\hline post & $\begin{array}{l}\text { Oak (Quercus sp. sect. Robur), } \\
9 \text { annual rings with bark-edge }\end{array}$ & & -26.8 & $1262 \pm 20$ & \\
\hline post 1292D & $\begin{array}{l}\text { Elm (Ulmus sp.), } 6 \text { annual } \\
\text { rings with bark-edge }\end{array}$ & Hd-24670 & -26.0 & 905 & cal AD 1040-1185 \\
\hline $\begin{array}{l}\text { wattle US } \\
1660\end{array}$ & $\begin{array}{l}\text { Hazel (Corylus avellana), } 5 \\
\text { annual rings with bark-edge }\end{array}$ & Hd-24673 & -29.0 & $1418 \pm 17$ & cal AD 600-660 \\
\hline $\begin{array}{l}\text { wattle US } \\
2121\end{array}$ & $\begin{array}{l}\text { Oak (Quercus } \\
6 \text { annual rings }\end{array}$ & Hd-24683 & -27.8 & $1293 \pm 21$ & cal AD 660-775 \\
\hline $\begin{array}{l}\text { wattle US } \\
1814\end{array}$ & $\begin{array}{l}3 \text { annual } \\
\text { e }\end{array}$ & Hd-24684 & -28.1 & $1321 \pm 19$ & cal AD 655-765 \\
\hline $\begin{array}{l}\text { wattle US } \\
2000\end{array}$ & $\begin{array}{l}\text { Oak (Quercus sp. sect. Robur), } \\
3 \text { rings with bark-edge }\end{array}$ & Hd-24687 & 6.9 & 127 & cal AD 665-780 \\
\hline $\begin{array}{l}\text { wattle US } \\
1882\end{array}$ & $\begin{array}{l}\text { Hophornbeam/hornbeam (Os- } \\
\text { trya/Carpinus), } 6 \text { annual rings } \\
\text { with bark-edge }\end{array}$ & Hd-24688 & -28.6 & $1283 \pm 19$ & cal AD 665-775 \\
\hline $\begin{array}{l}\text { wattle US } \\
1940\end{array}$ & $\begin{array}{l}\text { Oak (Quercus sp. sect. Robur), } \\
7 \text { annual rings with bark-edge }\end{array}$ & Hd-24703 & -28.6 & $1341 \pm 17$ & cal AD 650-685 \\
\hline $\begin{array}{l}\text { wattle US } \\
1757 \mathrm{~A}\end{array}$ & $\begin{array}{l}\text { Willow (Salix sp.), } 5 \text { annual } \\
\text { rings with bark-edge }\end{array}$ & Hd-24704 & -26.9 & $1270 \pm 17$ & cal AD 670-780 \\
\hline $\begin{array}{l}\text { wattle US } \\
1871\end{array}$ & $\begin{array}{l}\text { Hazel (Corylus avellana), } 3 \\
\text { annual rings with bark-edge }\end{array}$ & Hd-24706 & -28.1 & $1297 \pm 18$ & cal AD 660-775 \\
\hline
\end{tabular}

\section{DENDROCHRONOLOGICAL RESULTS}

The tree-ring measurement sequences from the 3 oak samples do not cross-match each other. The individual sequences were therefore compared both to oak chronologies from other sites and regions, and to chronologies for other species. Absolutely dated reference chronologies for Italian oak in this period do not exist, but the validity of cross-matching between Italian oak series and 
Swiss and German reference chronologies for the last 2 millennia has been documented (Corona 1989), even though further experimental evidence is required (Martinelli 1996). Cross-matching was therefore attempted against the following reference chronologies:

- the central-eastern German oak chronology (AD 960-1960) (Huber and Giertz-Siebenlist 1978);

- the central-western German oak chronology (AD 700-1964) (Hollstein 1980);

- the south-central German oak chronology (8480 BC-AD 2009) (Becker et al. 1985, Friedrich et al. 2004; M Friedrich, personal communication);

- the unpublished Swiss oak chronology (AD 924-1985) (P Gassmann, Neuchâtel Cantonal Museum Laboratory, personal communication).

The oak series were also compared to the alpine silver fir (Abies alba Mill.) chronology (AD 820 1961) (Becker and Giertz-Siebenlist 1970). None of these comparisons gave acceptable crossmatches.

The oak series were then compared to the floating regional oak chronology for early Medieval eastern Veneto (Martinelli and Kromer 2002) and to floating oak chronologies from other sites in Venice. One sample, the horizontal plank from structure US 1879, produced satisfactory visual and statistical cross-matches against the eastern Veneto chronology, when the final ring present on the sample corresponds to year 199 in the regional chronology, with the following cross-dating parameters: TBP (Baillie and Pilcher's $T$ value) 7.6; TH (Hollstein's $T$ value) $=6.6$; CDI (Cross-Date Index $)=384$; GLK $($ Gleichläufigkeit $)=77 \%$ (Rinntech 2003$)$. As the plank consisted only of heartwood, the sapwood having been removed during timber conversion, a minimum of $11 \mathrm{yr}$ must be added to this date to estimate the earliest possible felling of the tree concerned, following Corona (1970, 1974). Wiggle-match ${ }^{14} \mathrm{C}$ dating of the regional chronology (Martinelli and Kromer 2002) indicates a felling date in the mid-7th century cal AD or later.

Although there are relatively few dendrochronological studies of elm (Guibal 1998), an early Medieval floating elm chronology has been developed for Venice (Martinelli and Kromer 2002). Elm was widely used for structures in the Venice lagoon ( $\mathrm{O}$ Pignatelli, unpublished data) and is easily analyzed, hence the local elm chronology. Moreover, elm has often been shown to cross-match with oak from the same site (Lambert and Lavier 1991).

One of the elm samples, US 177, provided satisfactory visual and statistical cross-matches with the regional oak chronology for early Medieval eastern Veneto $(\mathrm{TBP}=4.5 ; \mathrm{TH}=4.3 ; \mathrm{CDI}=141$; GLK $=66 \%$ ) and with the floating elm chronology from the ex-Cinema San Marco site in Venice ( $\mathrm{TBP}=4.5 ; \mathrm{TH}=4.6 ; \mathrm{CDI}=93 ; \mathrm{GLK}=66 \%$ ), confirming the latter's cross-matching position with the regional oak chronology (see Martinelli and Kromer 2002). The final measured ring of US 177 corresponds to year 226 of the oak chronology.

\section{BAYESIAN MODELING}

The ${ }^{14} \mathrm{C}$ results, once calibrated (Stuiver and Reimer 1993; Reimer et al. 2009), provide accurate estimates, expressed as probability distributions, of the calendar dates of tree rings in individual samples, and, with appropriate adjustment for the samples' intrinsic ages, for the felling dates of the timbers concerned. These probability distributions, which are referred to as likelihoods in Bayesian chronological models (Buck et al. 1996), are independent of each other.

Bayesian modeling allows us to combine likelihoods with prior information about the relative ages of structures, which here may be inferred from stratigraphic relationships, to obtain a more precise 
probability distribution (posterior density estimate) for the date for each sample. Bayesian models can also incorporate other dating evidence, such as when a coin was minted, and estimate the dates of events not directly associated with individual samples, such as when a site was occupied or abandoned. Posterior density estimates are not independent of each other: they depend on all the dating information in a model, and may change if any component is altered (e.g. if another ${ }^{14} \mathrm{C}$ sample is dated). For this reason, they are conventionally given in italics.

It is not possible to show all the dated structures on a single plan or section drawing due to the complexity of the stratigraphy (Fozzati and Cester 2005), but stratigraphic relationships between dated structures can readily be represented in a Harris matrix (Figure 3). Our model includes 2 timbers (US 1879 and US 177) not dated directly by ${ }^{14} \mathrm{C}$. These timbers cross-match the eastern Veneto oak chronology, so a probability distribution for the date of the final ring of each timber can be obtained from a ${ }^{14} \mathrm{C}$ wiggle-match for this chronology (Martinelli and Kromer 2002). This does not give 2 independent likelihoods, as the age difference between the last ring of each timber is known from their cross-matching positions. We have calculated a probability distribution for the final ring of US 1879 (Figure 4), and cross-referenced this distribution in the model, with appropriate offsets, to obtain felling dates for US 1879 and US 177.

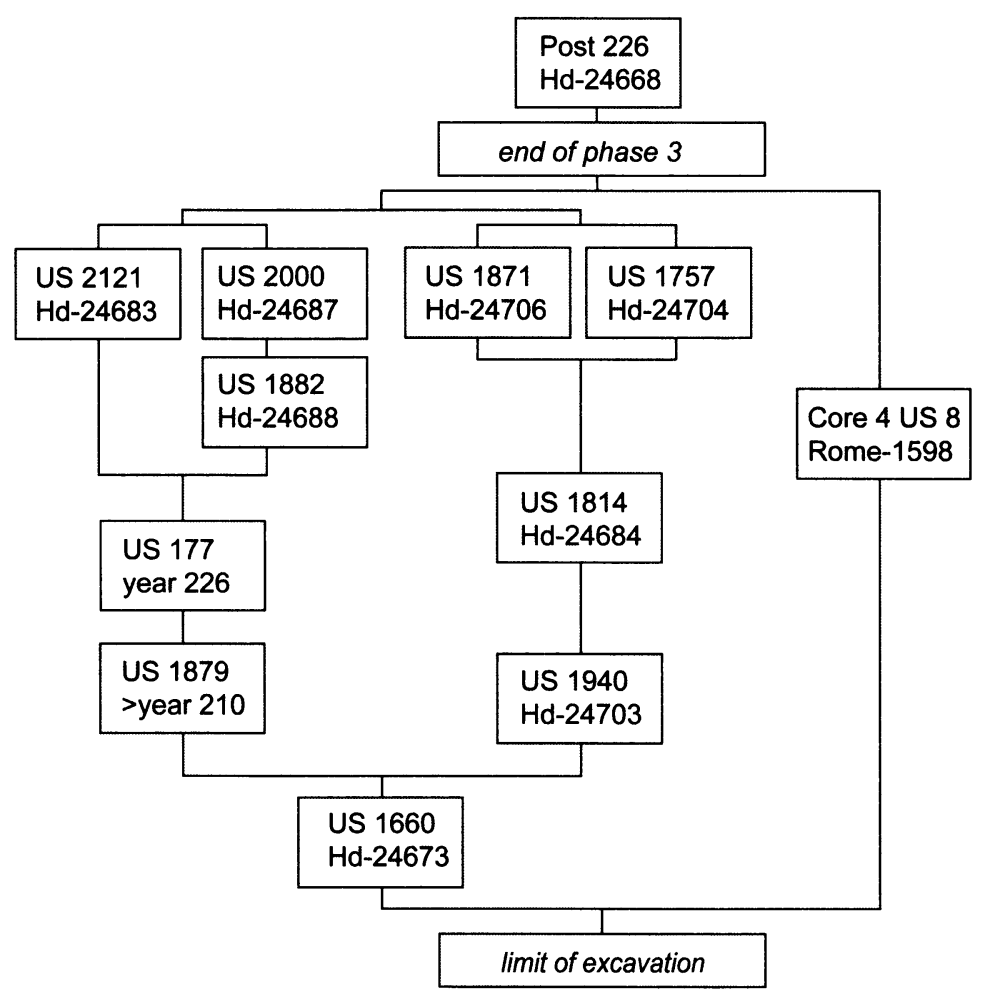

Figure 3 Harris matrix of dated samples, indicating the relative ages of timbers implicit in the stratigraphic relationships between structures. Aside from US 1879, each timber was complete to the bark edge. The outermost surviving ring of sample US 1879 was oak heartwood, dated to year 199 of the regional oak chronology, which implies that this timber was felled after year 210 (see text). 


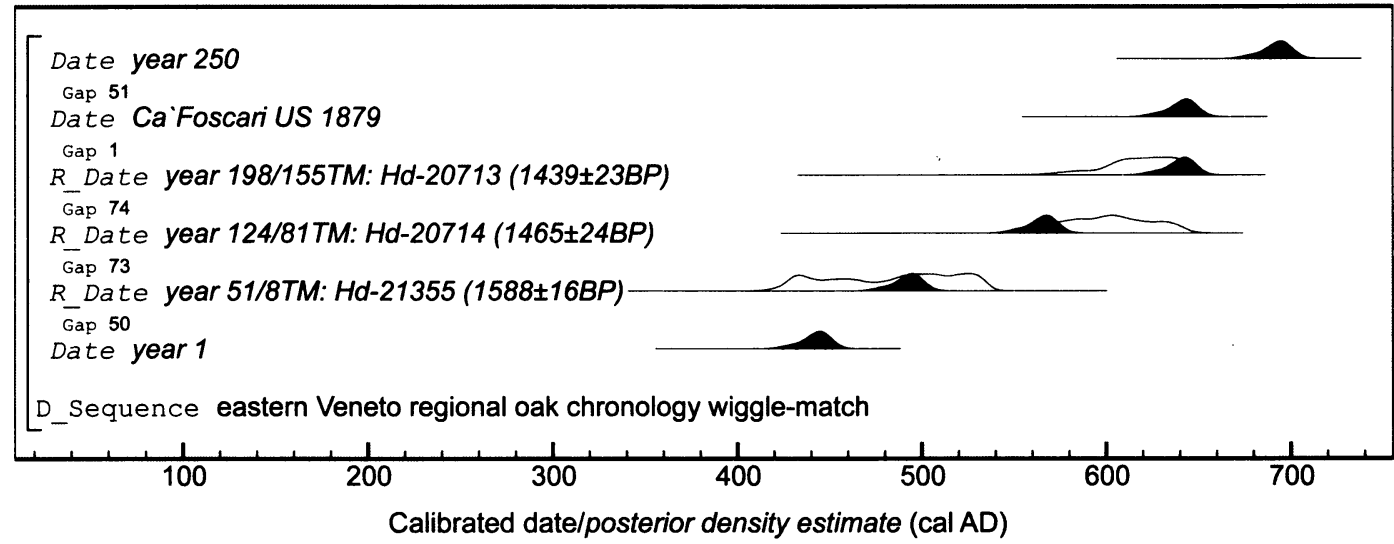

Figure 4 Wiggle-match for the eastern Veneto oak regional chronology, calculated using the D_Sequence function in OxCal v $4.1\left(\mathrm{~A}_{\text {comb }}=73.3 \%, \mathrm{~A}_{\mathrm{n}}=40.8 \%, n=3\right.$; Bronk Ramsey et al. 2001), with an estimated date for the final ring of timber Ca' Foscari US 1879 (year 199 of the regional chronology).

The Bayesian model (Figure 5) has good "dynamic agreement" $\left(A_{\text {model }}>60\right.$ : see Bronk Ramsey 2009), which indicates that the likelihoods are consistent with the relative dating of structures known from stratigraphy, and the implicit assumption that the structures were made of freshly felled wood. The posterior density estimates for individual samples are therefore interpreted as the construction dates of the relevant structures. The model also estimates the date of the beginning and end of this phase of occupation, and of the First and Last structure in this phase (Figure 5). Rome-1598, which is not associated with one of the stratified structures, fits within this phase of activity $(A>60$ : Bronk Ramsey 1995), and should not be interpreted as evidence of an earlier construction episode at $\mathrm{Ca}$ ' Foscari. The posterior density estimate for the final ring of sample US 1879 (Figure 5, inset) is consistent with its likelihood, given by the regional chronology wiggle-match $(A=109.7 \%$ : Bronk Ramsey 1995).

\section{DISCUSSION}

Our model estimates that the latest volparoni structure at Ca' Foscari was built in cal AD 690-770 or 695-730 (Figure 5: Ca' Foscari Last, 95\% or 68\% probability). This estimate is probably valid, as there was no evidence that these deposits had been truncated by later constructions, but the excavation did not reach natural soil, so the model's estimate of cal AD 610-665 (Figure 5: Ca' Foscari First, 95\% probability) for the first structure may be regarded as a terminus ante quem for land reclamation at Ca' Foscari.

Volparoni structures have recently been excavated at several other sites in central Venice, including the Teatro Malibran, near Rialto, and the ex-Cinema San Marco, near Piazza San Marco (Figure 1). The eastern Veneto oak chronology (Martinelli and Kromer 2002) is based mainly on planks from the Teatro Malibran and ex-Cinema San Marco sites, which must therefore overlap in date with the volparoni phase at $\mathrm{Ca}$ ' Foscari. Full stratigraphic sequences for these sites are not yet available, but a preliminary combined Bayesian model was created (Figure 6), incorporating the Ca' Foscari model and results from the ex-Cinema San Marco (Valle and Anglani, in press), where we simply assumed that all the dated timbers (whether dated by ${ }^{14} \mathrm{C}$ or dendrochronological cross-matching) represent a single "bounded" phase of activity (Bronk Ramsey 2000). 


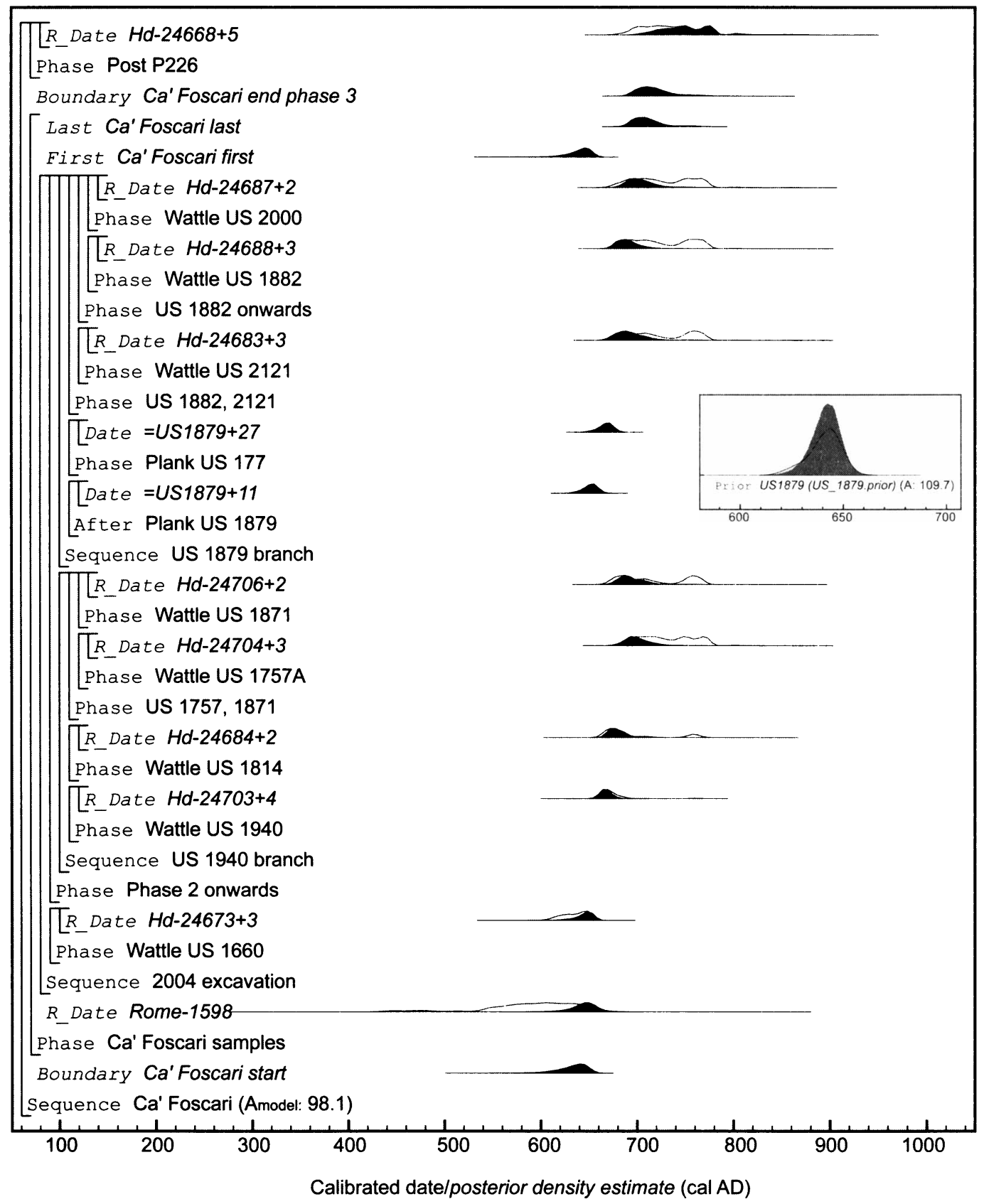

Figure 5 A Bayesian chronological model, implemented in OxCal v 4.1 (Bronk Ramsey 2009); the keywords and square brackets define the relative dating (shown in Figure 3) incorporated in the model. Distributions in outline are likelihoods for the felling dates of the timbers concerned, obtained by shifting the probability distribution of each calibrated ${ }^{14} \mathrm{C}$ result by half the number of annual rings in the sample (Table 2). The single likelihood associated with both Plank US 177 and Plank US 1879 is the distribution Ca' Foscari US 1879 (Figure 4). Solid distributions are posterior density estimates of the felling dates and associated events, including the final ring of US 1879 (inset). The satisfactory index of agreement $\left(A_{\text {model }}>60\right)$ indicates overall consistency between likelihoods and posterior density estimates. 


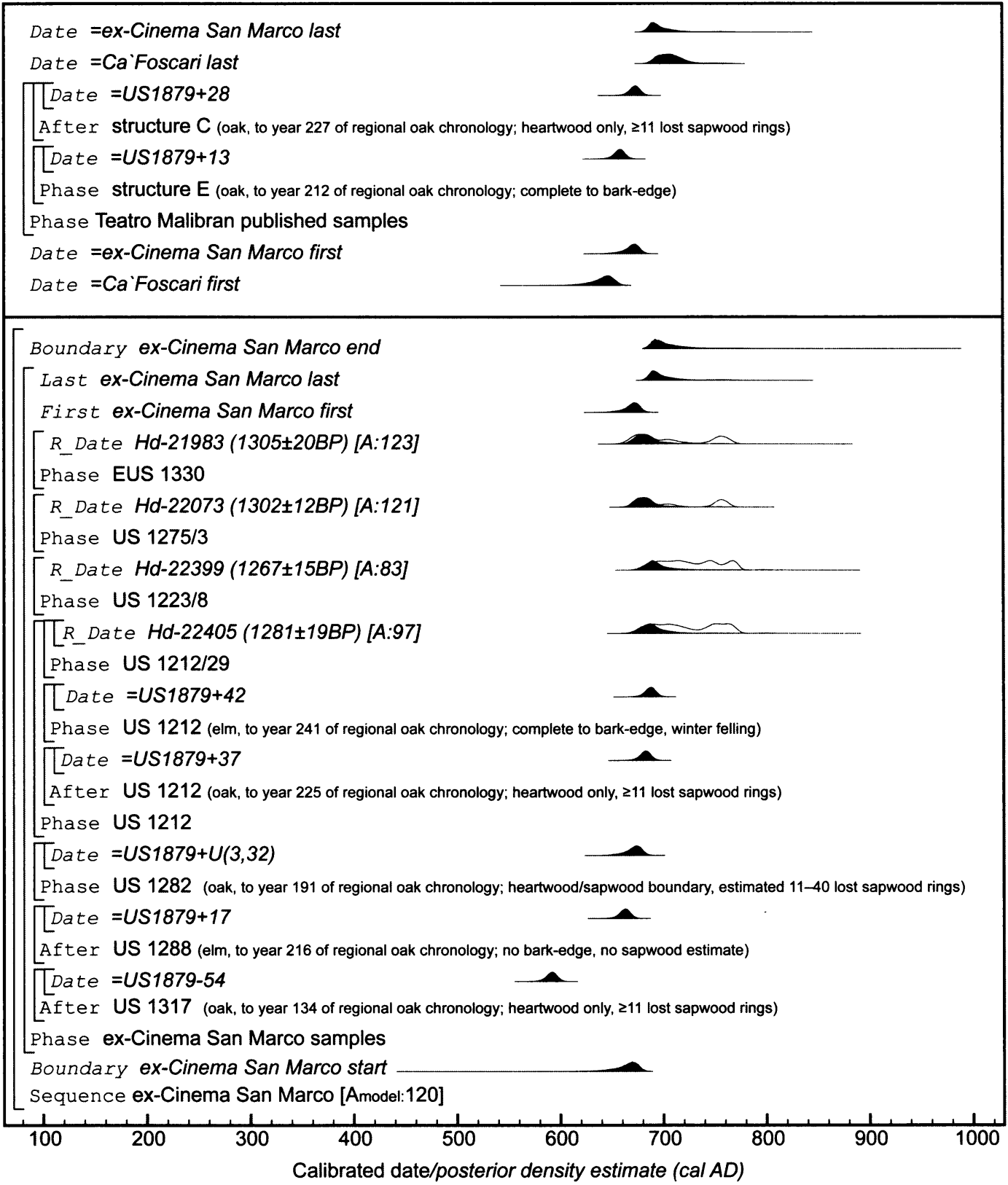

Figure 6 Combined chronological model, including data from Ca' Foscari and the ex-Cinema San Marco site (Valle and Anglani, in press). The likelihoods and structure of the Ca' Foscari section, not shown here, are identical to those in the model shown in Figure 5, but the posterior density estimates are slightly different, because the estimated date of US 1879 is also affected by the ex-Cinema San Marco results (shown in the lower panel). The upper panel shows the combined model's estimated dates of the first and last volparoni structures at Ca' Foscari and the ex-Cinema San Marco, and the dates of 2 structures at the Teatro Malibran site, based on dendrochronological cross-matching (Martinelli and Kromer 2002) and the combined model's posterior density estimate for US 1879. 
The combined model does not assume that there is any chronological relationship between the sites, other than the known dendrochronological cross-matches between some timbers. The model crossreferences the dates of cross-matched timbers from the ex-Cinema San Marco to that of the final ring of sample US 1879 from Ca' Foscari, with offsets corresponding to the cross-matching positions. The posterior density estimate for US 1879 is therefore affected by ${ }^{14} \mathrm{C}$ results from both sites. In the original wiggle-match (Martinelli and Kromer 2002), year 250 of the eastern Veneto regional oak chronology was dated to cal AD $699 \pm 21(2 \sigma)$, which would date the outermost surviving ring of US 1879 (year 199 of the regional oak chronology) to cal AD $648 \pm 21(2 \sigma)$. In our combined model, US 1879 is dated to cal AD 634-657 (95\% probability) or cal AD $646 \pm 11$ (2 $\sigma$, Figure 7).

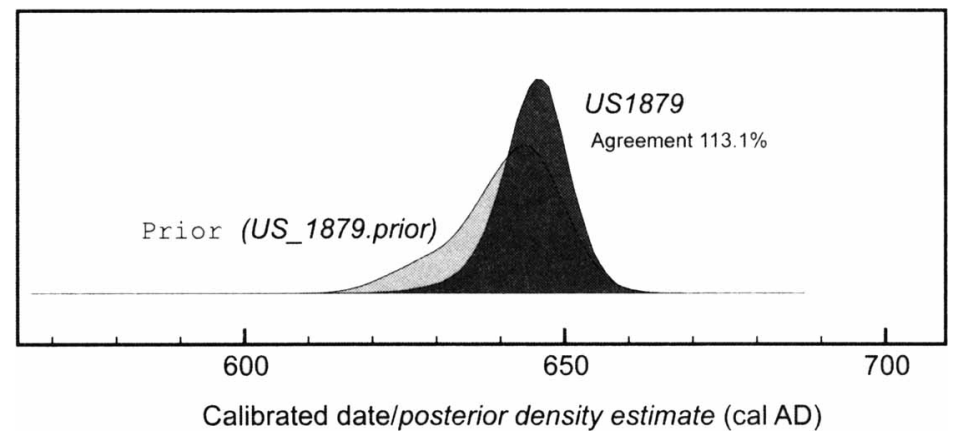

Figure 7 Estimated date of the final ring of sample US 1879. The outline distribution is derived from the model shown in Figure 4; the solid distribution is the posterior density estimate of the date of the same ring, based on the model shown in Figure 6.

The First and Last dates for each site estimated by the combined model bracket the dates of structures at the Teatro Malibran based on dendrochronological cross-matching (Martinelli and Kromer 2002; in Figure 6, we have used the combined model's posterior density estimate, US 1879, with appropriate offsets, for the dates of these structures). Additional unpublished ${ }^{14} \mathrm{C}$ results from Teatro Malibran support the interpretation that the 3 sites are almost exactly contemporaneous. The earliest volparoni structures at all 3 sites apparently date to the 7th century, but in each case excavations did not reach natural sediment, so the model estimates do not indicate the order in which these sites were developed. Nevertheless, the results show that land reclamation had begun in at least 3 areas of Venice by the later 7 th century.

The last volparoni structure at $\mathrm{Ca}$ ' Foscari and the ex-Cinema San Marco apparently dates to within decades of cal AD 700, which may imply a pause in the process of land reclamation in central Venice at the beginning of the 8th century. A possible explanation is the suggestion by Vito Favero that the sea level rose from 1.6 to $1.0 \mathrm{~m}$ below modern sea level between the 5 th and 7 th centuries, before falling back to $1.3 \mathrm{~m}$ below modern sea level in the 8th century (Tuzzato et al. 1993:78-80; chronology based on artifact attributions). There is some support for this idea at Ca' Foscari, where successive volparoni structures serve to raise the ground level, and subsequent waterfronts are slightly lower (see above). Although volparoni structures at the other sites are at similar depths with respect to modern sea level, precise altitudinal comparisons are difficult, as these levels have been compressed to some degree by later constructions; further work on this issue is required. 


\section{CONCLUSION}

Recent excavations demonstrate the remarkable preservation of volparoni structures in Venice, whose survival may permit an accurate reconstruction of the early growth of the city, if archaeologists are able to take full advantage of the access provided by development activity. Historical evidence, such as church foundations, provide only a partial picture of the expansion of the early Medieval city, and then only from the 9th century onwards (Gelichi 2007). The Bayesian models presented here bring together the relative dating embodied in a complex stratigraphic sequence, calibrated dates from precise ${ }^{14} \mathrm{C}$ measurements of short-lived timbers from volparoni structures, and exact age differences known from dendrochronological analysis of larger timbers. The models show that at Ca' Foscari, on the bank of what would become the Grand Canal, an initial stage of land reclamation was already underway by the middle of the 7th century cal $\mathrm{AD}$, and was completed by the early 8 th century. At about the same time, land reclamation was also in progress $800 \mathrm{~m}$ to the east, at the ex-Cinema San Marco site, and $700 \mathrm{~m}$ further north, at the Teatro Malibran site. Whether Venice was already a large settlement by the late 7 th century or whether these sites were just scattered islands remains to be discovered, but our results suggest that despite the scarcity of documentary evidence and closely datable artifacts in this period, a detailed chronology of the earliest structures can be realized by a consistent application of scientific dating methods and Bayesian modeling.

\section{ACKNOWLEDGMENTS}

We would like to thank the Ministero per i Beni e le Attività Culturali, Soprintendenza per i Beni Archeologici del Veneto, for permission to use Figures 1 and 2. The excavations and postexcavation analyses were funded by Università $\mathrm{Ca}^{\prime}$ Foscari, Venezia.

\section{REFERENCES}

Ammerman AJ, De Min M, Housley R. 1992. New evidence on the origins of Venice. Antiquity 66(253): 913-6.

Aniol RW. 1983. Tree-ring analysis using CATRAS. Dendrochronologia 1:45-53.

Baillie MGL. 1982. Tree-Ring Dating and Archaeology. London: Croom Helm.

Becker B, Giertz-Siebenlist V. 1970. Eine über 1100 jährige mitteleuropäische Tannenchronologie. Flora 159: 310-46.

Becker B, Billamboz A, Egger H, Gassmann P, Orcel A, Orcel C, Ruoff U, editors. 1985. Dendrochronologie in der Ur- und Frühgeschichte: Die Absolute Datierung von Pfahlbausiedlungen Nördlich der Alpen im Jahrringkalender Mitteleuropas. Basel: Verlag Schweizerische Gesellschaft für Ur- und Frühgeschichte.

Bronk Ramsey C. 1995. Radiocarbon calibration and analysis of stratigraphy: the OxCal program. Radiocarbon 37(2):425-30.

Bronk Ramsey C. 2000. Comment on 'The use of Bayesian statistics for ${ }^{14} \mathrm{C}$ dates of chronologically ordered samples: a critical analysis.' Radiocarbon 42(2):199202.

Bronk Ramsey C. 2009. Bayesian analysis of radiocarbon dates. Radiocarbon 51(1):337-60.

Bronk Ramsey C, van der Plicht J, Weninger B. 2001.
'Wiggle matching' radiocarbon dates. Radiocarbon 43(2A):381-9.

Buck CE, Cavanagh WG, Litton CD. 1996. Bayesian Approach to Interpreting Archaeological Data. Chichester: Wiley.

Calderoni G, Petrone V. 1992. Department of Earth Sciences at the University of Rome radiocarbon dates I. Radiocarbon 34(1):105-13.

Canal E. 1998. Testimonianza Archeologiche nella Laguna di Venezia di Eta' Antica. Cavallino di Venezia: Edizioni del Vento.

Corona E. 1970. Cerchie dell'alburno in tronchi di rovere. L'Italia Forestale e Montana 25(3):156-8.

Corona E. 1974. Ricostruzione dell'alburno in legnami sommersi. Geoarcheologia 1-2:19-22.

Corona E. 1989. Significato dendrocronologico delle querce. Monti e Boschi 1:6-8.

Fozzati L, Cester R. 2005. L'archeologia d'emergenza nelle operazioni di restauro: cronaca del cantiere di Cà Foscari. In: Pilo GM, De Rossi L, Alessandri D, Zuanier F, editors. Ca' Foscari. Storia e Restauro del Palazzo dell'Università di Venezia. Venice: Marsilio Editori. p 188-200.

Friedrich M, Remmele S, Kromer B, Hofmann J, Spurk M, Kaiser KF, Orcel Ch, Küppers M. 2004. The 12,460-year Hohenheim oak and pine tree-ring chronology from central Europe-a unique annual record 
for radiocarbon calibration and paleoenvironment reconstructions. Radiocarbon 46(3):1111-22.

Fritts HC. 1976. Tree Rings and Climate. New York: Academic Press.

Gelichi S. 2007. Flourishing places in North-Eastern Italy: towns and emporia between late antiquity and the Carolingian age. In: Henning J, editor. Post-Roman Towns, Trade and Settlement in Europe and Byzantium. Volume 1: The Heirs of the Roman West. Berlin: Walter de Gruyter. p 77-104.

Guibal F. 1998. Dendrocronologie et dendromorphologie. In: Volpe G, editor. Archeologia Subacquea. Come Opera l'Archeologo. Storie delle Acque. VIII Ciclo di Lezioni sulla Ricerca applicata in Archeologia. Florence: Edizioni all'Insegna del Giglio. p 425-46.

Hollstein E. 1980. Mitteleuropaeische Eichenchronologie. Trier Grabungen und Forschungen 11.

Huber B, Giertz-Siebenlist V. 1978 Our 1000-year oak annual-ring chronology. In: Fletcher J, editor. Dendrochronology in Europe. Principles, Interpretations and Applications to Archaeology and History. Oxford: British Archaeological Reports, International Series 51. p 27-32.

Kromer B, Münnich KO. 1992. $\mathrm{CO}_{2}$ gas proportional counting in radiocarbon dating - review and perspective. In: Taylor RE, Long A, Kra RS, editors. Radiocarbon After Four Decades: An Interdisciplinary Perspective. New York: Springer. p 184-97.

Lambert G-N, Lavier C. 1983. Sciences et archéologie: application de la dendrocronologie a l'archéologie. Bulletin de la Société d'Histoire Naturelle du Doubs 81:63-87.

Martinelli N. 1996. Datazioni dendrocronologiche per l'età del Bronzo dell'area alpina. In: Randsborg K, editor. Absolute Chronology: Archaeological Europe 2500-500 B.C. Acta Archaeologica, 67, Acta Archae- ologica Supplementa I. p 315-26.

Martinelli N, Kromer B. 2002. A new oak chronology for early medieval times in the Veneto region. In: D'Amico C, editor. Atti del Secondo Congresso $\mathrm{Na}$ zionale di Archeometria. Bologna. p 293-304.

Reimer PJ, Baillie MGL, Bard E, Bayliss A, Beck JW, Blackwell PG, Bronk Ramsey C, Buck CE, Burr GS, Edwards RL, Friedrich M, Grootes PM, Guilderson TP, Hajdas I, Heaton TJ, Hogg AG, Hughen KA, Kaiser KF, Kromer B, McCormac FG, Manning SW, Reimer RW, Richards DA, Southon JR, Talamo S, Turney CSM, van der Plicht J, Weyhenmeyer CE. 2009. IntCa109 and Marine09 radiocarbon age calibration curves, 0-50,000 years cal BP. Radiocarbon 51(4): 1111-50.

Rinntech. 2003. TSAP-Win ${ }^{\mathrm{TM}}$. Time series analysis and presentation for dendrochronology and related applications. Version 0.59 for Microsoft Windows 98, 2000, XP. User Reference. Heidelberg: Rinntech.

Stuiver M, Polach HA. 1977. Discussion: reporting of ${ }^{14} \mathrm{C}$ data. Radiocarbon 19(3):355-63.

Stuiver M, Reimer PJ. 1986. A computer program for radiocarbon age calculation. Radiocarbon 28(2B): 1022-30.

Stuiver M, Reimer PJ. 1993. Extended ${ }^{14} \mathrm{C}$ data base and revised CALIB $3.0{ }^{14} \mathrm{C}$ age calibration program. $R a$ diocarbon 35(1):215-30.

Tuzzato S, Favaro V, Vinals MJ. 1993. Venezia. San Pietro di Castello a Venezia. Nota preliminare dopo la campagna 1992. Quaderni di Archeologia del Veneto IX:72-80.

Valle G, Anglani L. In press. Venezia ex-cinema San Marco. Le fasi medievali. In: I Vasai del Leone: $\mathrm{Ce}$ ramiche nel Veneto e del Veneto tra VI e XVI secolo. Atti del Convegno Internazionale, Venice, 13-15 April 2004. 